\title{
Microbial diversity in deep sediments of the Benguela Upwelling System
}

\author{
Hendrik Schäfer ${ }^{1,2}$, Timothy G. Ferdelman ${ }^{1}$, Henrik Fossing ${ }^{1,3}$, Gerard Muyzer ${ }^{1,4, *}$ \\ ${ }^{1}$ Max Planck Institute for Marine Microbiology, Celsiusstrasse 1, 28359 Bremen, Germany \\ ${ }^{2}$ Present address: Warwick HRI, University of Warwick, Wellesbourne CV35 9EF, UK \\ ${ }^{3}$ Present address: National Environmental Research Institute, Vejlsøvej 25, 8600 Silkeborg, Denmark \\ ${ }^{4}$ Present address: Dept. of Biotechnology, Delft University of Technology, Julianalaan 67, 2628 BC Delft, The Netherlands
}

\begin{abstract}
The microbial diversity of sulfate-reducing and methanogenic subsurface sediments of the Benguela Upwelling System was analyzed using 16S rRNA gene-directed molecular methods. Communities mediating anaerobic oxidation of methane (AOM) in the sulfate-methane transition zone (SMTZ) were also targeted. Denaturing gradient gel electrophoresis (DGGE) of DNA extracted from sediment samples showed the presence of complex bacterial communities in the sediment zones above and below the SMTZ, whereas only 3 DGGE-defined populations were detected in the SMTZ. Sequencing of excised DNA fragments revealed the presence of bacterial populations related to sulfatereducing bacteria (SRB) and those distantly related to the Haloanaerobium phylum. One of the populations detected at the SMTZ was closely related to SRB and to bacterial populations detected at mud volcanoes in the Black Sea. Comparative analysis of sequences from a clone library made with genomic DNA from the SMTZ and primers specific for archaeal 16S rRNA genes revealed members of 5 different lineages, including unusual crenarchaeal ribosomal RNA sequences. None of the archaeal sequences, however, was related to groups previously implicated in anaerobic methane oxidation.
\end{abstract}

KEY WORDS: Anaerobic methane oxidation . Geomicrobiology $\cdot$ Subsurface microbiology $\cdot$ Sulfatemethane transition zone

Resale or republication not permitted without written consent of the publisher

\section{INTRODUCTION}

The Benguela Upwelling System is one of the most productive upwelling areas in the world ocean. Sediments on the continental slope off Namibia that underlie the Benguela Upwelling are characterized by high

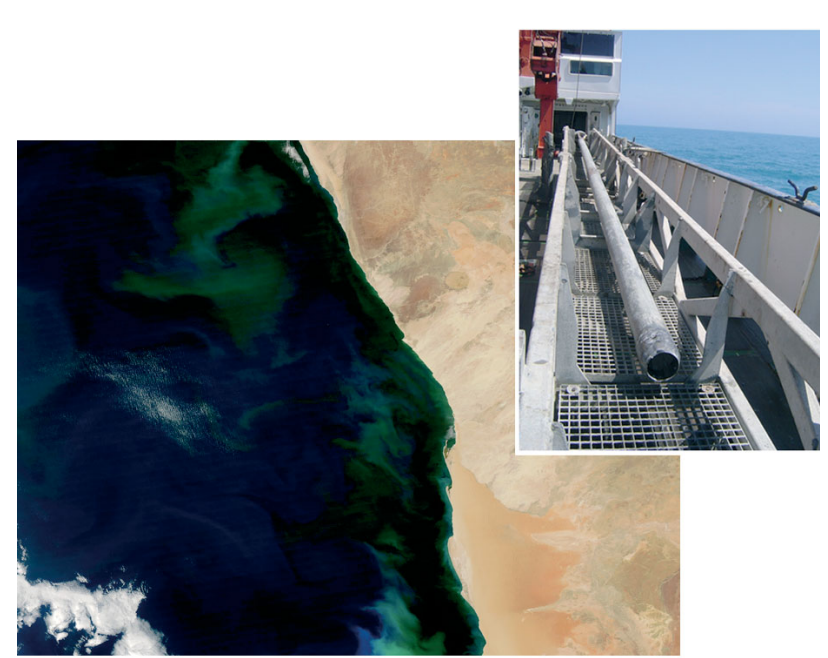

Satellite photograph of the Benguela Upwelling System; inset: a gravity core that has been retrieved from the sea floor

Photo: NASA; inset: T. G. Ferdelman

organic carbon contents and high rates of anaerobic carbon turnover (Ferdelman et al. 1999). The pronounced rates of carbon turnover lead to depletion of sulfate-bearing pore waters within several meters of the sediment-water interface (Niewöhner et al. 1998). In the heart of the organic carbon deposition zone on the Namibian continental slope, pore water profiles of sulfate, sulfide and methane show a distinct sulfatemethane transition zone (SMTZ) at a depth of several meters (Fig. 1, modified from Fossing et al. 2000). In the surface and sub-surface sediments down to $3 \mathrm{~m}$ sediment depth, sulfate reduction is the principal anaerobic terminal oxidation pathway. Pore water profiles (Fossing et al. 2000) reveal 3 distinct biogeochem- 


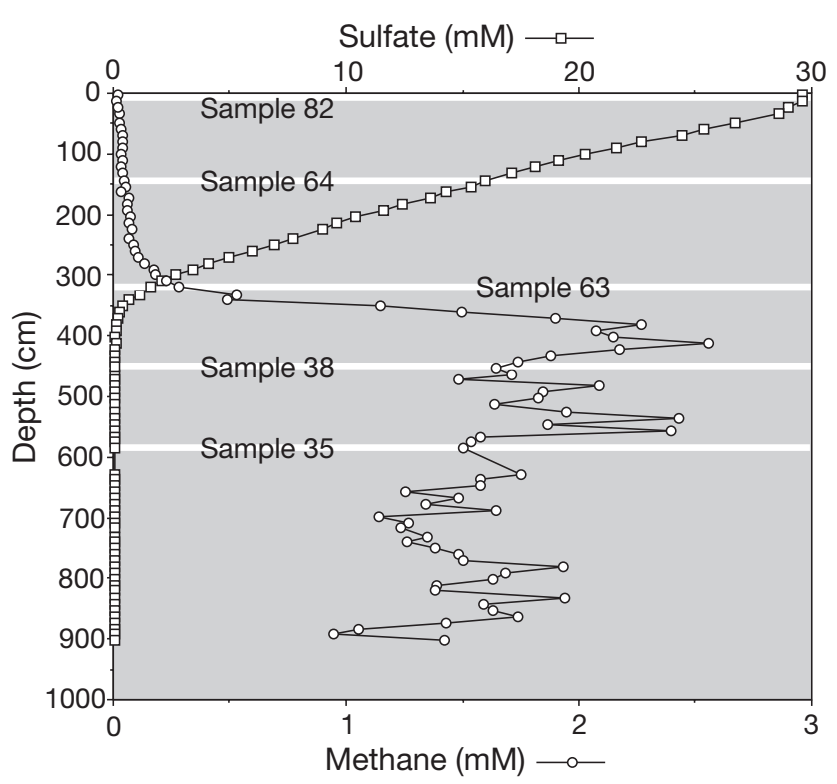

Fig. 1. Depth profile of sulfate and methane concentrations at Stn GeoB3703 (data from Fossing et al. 2000). White lines indicate the depths sampled for molecular biological analysis

ical zones in the sediments at Stn GeoB 3703: (1) a sulfate-reducing zone between the surface and $250 \mathrm{~cm}$ depth; (2) a SMTZ between 250 and $450 \mathrm{~cm}$ depth; and (3) a deeper methanogenic zone. Sulfide was present from 30 to $950 \mathrm{~cm}$ and exhibited peak concentrations of $8.5 \mathrm{mM}$ in the SMTZ. (Fossing et al. 2000). A near 1:1 stoichiometry of upward methane and downward sulfate fluxes in the SMTZ (Niewöhner et al. 1998), matched by measured rates of sulfate reduction (Fossing et al. 2000), suggested that the anaerobic oxidation of methane was coupled to the reduction of sulfate. Consortia of sulfate-reducing bacteria (SRB) and Archaea related to methanogens acting in reverse may potentially mediate this process (Hoehler et al. 1994, Hinrichs et al. 1999).

The involvement of Archaea in anaerobic oxidation of methane (AOM) has been demonstrated in a range of field samples-principally from methane seep sites - based on ${ }^{13} \mathrm{C}$-depleted archaeal lipid biomarkers by newly discovered groups of Archaea (Hinrichs et al. 1999, Boetius et al. 2000, Pancost et al. 2000) and there is direct experimental evidence that SRB and Archaea form consortia that oxidize methane anaerobically (Nauhaus et al. 2002). Close associations of SRB-related Bacteria and methanogen-related Archaea have been observed by fluorescent in situ hybridization (FISH), and a number of groups of anaerobic methane-oxidizing Archaea (so-called ANME groups) have been defined, with varying sulfatereducing partners and morphologies (Boetius et al. 2000, Orphan et al. 2002, Knittel et al. 2005). Analysis of ${ }^{13} \mathrm{C}$-signatures by secondary ion mass spectrometry of single cells identified by FISH has confirmed that ANME Archaea are methanotrophs (Orphan et al. 2002). The SRB partner in methanotrophic Archaeal SRB consortia was suggested to be essential in order to keep $\mathrm{H}_{2}$ partial pressure at a minimum in order to make sulfate-dependent oxidation of methane according to the reverse methanogenesis model energetically favorable (Hoehler et al. 1994). Using sediments from methane hydrate bearing sediments containing ANME/SRB consortia, Nauhaus et al. (2002) tested the effect on sulfide production of several compounds that could potentially be the intermediate shuttled from methanotroph to the SRB partner. However, sulfide production was not stimulated by hydrogen, carbon monoxide (CO), acetate, formate or methanol, suggesting that another intermediate may play a role. Recently, it has been suggested that the intermediate may be methanethiol, as inhibition of anaerobic $\mathrm{CH}_{4}$ oxidation in sediment samples was observed upon exposure to methanethiol (Moran et al. 2008).

ANME Archaea are widely distributed in marine sediments including cold seeps, hydrothermally active sediments, sediments bearing methane hydrate, mud volcanoes, or sediments otherwise affected by methane-driven gas or fluid flow (Thomsen et al. 2001, Orphan et al. 2002, Teske et al. 2002, Inagaki et al. 2003, 2004, Knittel et al. 2005, Stadnitskaia et al. 2005, Treude et al. 2005a, Parkes et al. 2007). However, ANME Archea have not always appeared in typical continental margin sedimentary regimes where the SMTZ is regulated by the burial of detrital organic carbon. A number of studies have targeted the sediments obtained during Ocean Drilling Program (ODP) Leg 201 from the Peru Margin (Jørgensen et al. 2006). Biddle et al. (2006) showed that heterotrophic Archaea belonging to the Marine Benthic Group B (MBG-B) and the Miscellaneous Crenarchaeal Group (MCG), instead of the known methanotrophic Archaea, are dominating the SMTZs of subsurface sediments off Peru. Parkes et al. (2005) and Sørensen \& Teske (2006) also do not report the presence of ANME- related microbes within the SMTZ at neighboring sites. MCG Archaea dominate 16S rRNA gene libraries in both studies.

In spite of the enormous extent of sedimentary subseafloor habitats that are dominated by diffusive transport, especially along continental margins, studies of microbial diversity within these systems remain underrepresented. Many of the key studies have focused on ODP sites from the Peru Margin. Other sedimentary sites have been strongly affected by enhanced gas fluxes from large reservoirs of shallow gas such as in the Skagerrak (Parkes et al. 2007) and Eckenförder Bay (Treude et al. 2005b), or very shallow sedimentary 
systems such as Aarhus Bay (Thomsen et al. 2001). Continental margin sediments associated with the Benguela Upwelling represent one of the major organic carbon burial centers in the global ocean, whose microbial diversity has been little studied. Furthermore, Stn GeoB3703 represents a site where heterotrophic degradation of organic carbon compounds dominates the overall carbon flow. Methanotrophic sulfate reduction (i.e. sulfate reduction associated with $\mathrm{AOM}$ ) represents only $6 \%$ of the total areal sulfate reduction at this site (Fossing et al. 2000).

The aim of the present study was to characterize the microbial communities of sediments from the Benguela Upwelling System by molecular biological methods and to identify dominant microbial populations in deep subsurface sediment layers. Samples for molecular analysis of sub-surface microbial communities were taken in relation to dominant biogeochemical zones as defined by the distributions of sulfate and methane (Fig. 1). The issues of foremost interest were the distributions of SRB in the surface layer, as well as the composition of the microbial community at the SMTZ, and into the methanogenic zone. Our study contributes to the debate on subsurface microbiology by identifying the Bacteria and Archaea that are present in different sediment layers, including the SMTZ, of a sediment dominated by heterotrophic carbon mineralization.

\section{MATERIALS AND METHODS}

Sediment sampling and DNA extraction. The analyses concentrated on sediment samples from the continental slope off Namibia during research cruise M34-2 with RV 'Meteor' in 1996. A 9 m long sediment gravity core was obtained from Stn GeoB3703 (2531.0' S, $13^{\circ} 14.0^{\prime} E_{;} 1372 \mathrm{~m}$ water depth). The core was immediately sectioned into $1 \mathrm{~m}$ long sub-sections and brought into a $4^{\circ} \mathrm{C}$ thermostated laboratory for subsampling (see Fossing et al. 2000, for details on subsampling). Sub-samples for molecular biological analysis were immediately frozen at $-20^{\circ} \mathrm{C}$, then stored at $-80^{\circ} \mathrm{C}$, and analyzed within 6 months after collection. DNA was obtained from about $5 \mathrm{~g}$ of sediment following the protocol of Zhou et al. (1996).

PCR, DGGE, DNA sequencing and Southern blotting and hybridization. Primers 341F-GC and 907RC were used to amplify bacterial 16S rRNA gene fragments that were suited for DGGE analysis in polyacrylamide gels containing a linear gradient from 20 to $70 \%$ denaturants as described previously (Schäfer et al. 2000). Bovine serum albumin (BSA; $3 \mu \mathrm{g} \mathrm{l}^{-1}$ final concentration) was used in all PCR reactions to alleviate inhibition of Taq polymerase by humic substances that were co-extracted with nucleic acids from the sediments. Individual DGGE bands were excised, re-amplified, and sequenced as described previously (Schäfer \& Muyzer 2001). DGGE banding patterns were transferred to nylon membranes (Hybond+, Amersham) as described by Muyzer et al. (1998), and hybridized with ${ }^{32} \mathrm{P}$-labeled oligonucleotide probes specific for SRB (Devereux et al. 1992) as described by Santegoeds et al. (1998). For the analysis of the archaeal community composition 16S rRNA gene fragments were amplified using primers 344F and 915R as described by Casamayor et al. (2000), but without the GC-clamp. These PCR products were cloned into vector pGEM-T easy (Promega) and sequenced as described previously (Schäfer et al. 2000, Schäfer \& Muyzer 2001). Sequences obtained in the present study have been deposited in the EMBL database under accession numbers AJ305054 to AJ305084.

Comparative sequence analysis. Comparative sequence analysis was performed using ARB (Ludwig et al. 2004). Trees were calculated using the AxML option in ARB (maximum likelihood) using 16S rRNA gene alignment columns corresponding to Escherichia coli positions 424 and 873 for Bacteria, and positions 376 and 902 for Archaea. The general topology of trees calculated using distance or parsimony criteria was similar (results not shown).

\section{RESULTS AND DISCUSSION}

\section{DGGE analysis of bacterial diversity}

DGGE analysis of bacterial 16S rRNA gene fragments revealed different but reproducible genetic fingerprints for samples from different depths of the sediment (Fig. 2). The overall patterns demonstrated striking differences between samples located above or below the SMTZ, and from the SMTZ itself. Numbers of detected bands in DGGE patterns suggested that genetic richness was higher towards the surface (patterns of Samples 82 and 64 contained 19 and 20 bands, respectively), lowest at the SMTZ (3 bands for Sample 63 ), and intermediate in the methane zone (8 and 10 bands for Samples 38 and 35, respectively). Although the number of DGGE bands most likely underestimates the true diversity of these samples, the higher richness of dominant populations in the upper regions of the sediment is likely to reflect a greater number of available niches in the sediment (e.g. diversity of electron donors or higher temporal variability than at greater depths). All of the bacterial 16S rRNA gene sequences determined in this study were related to sequences that were retrieved from other marine sediments, including methane hydrate sites or hydrocarbon seeps, or from bacterial strains isolated from marine sediments (Fig. 3). 


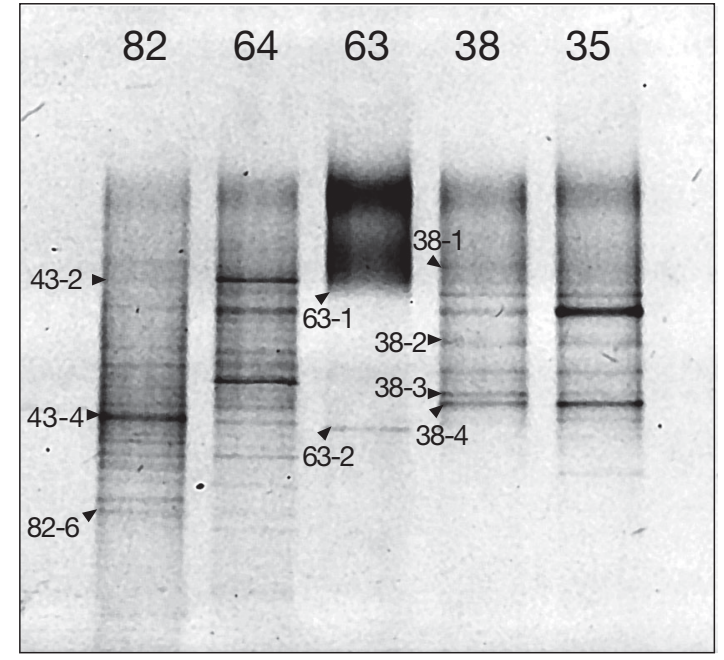

Fig. 2. DGGE analysis of bacterial 16S rRNA gene fragments obtained from sediment samples (numbers indicated at the top of the lanes; cf. Fig. 1) from Stn GeoB3703. Arrows and numbers indicate the DGGE bands that were sequenced. 43-2 and 43-4: DGGE bands that were excised from the DGGE profile of the surface sample of another core, which had a similar pattern to Sample 82, and the bands co-migrated with the indicated ones in Sample 82
The distribution of identified community members is summarized in Table 1. DGGE bands 38-1, 63-1 and 43-2 represented populations that were detected in all sediment horizons analyzed. These populations were also closely related to populations detected at the Nankai Trough (Kormas et al. 2003), in Mediterranean mud volcanoes (GenBank accession no. AY592406) and hydrate bearing sediments at the Cascadia Margin (Inagaki et al. 2006b). Distribution of these closely related populations throughout the sediment, i.e. above, at and below the SMTZ, could indicate that these populations shared similar physiologies or that they are physiologically versatile and not dependent on specific electron acceptors for anaerobic respiration and have a fermentative lifestyle.

Closely related populations represented by DGGE bands 38-2, 38-3 and 38-4 appeared to be confined to depths below the SMTZ; the sequences were affiliated to members of the Chloroflexi. Related sequences were also from deep subsurface sediments, e.g. ODP sites on the Peru Margin (Parkes et al. 2005, Inagaki et al. 2006b, Webster et al. 2006), Nankai Trough (clone ODP1176A6H_1_B from 51 mbsf; Kormas et al. 2003), a deep subsurface paleosol (Chandler et al. 1998) the

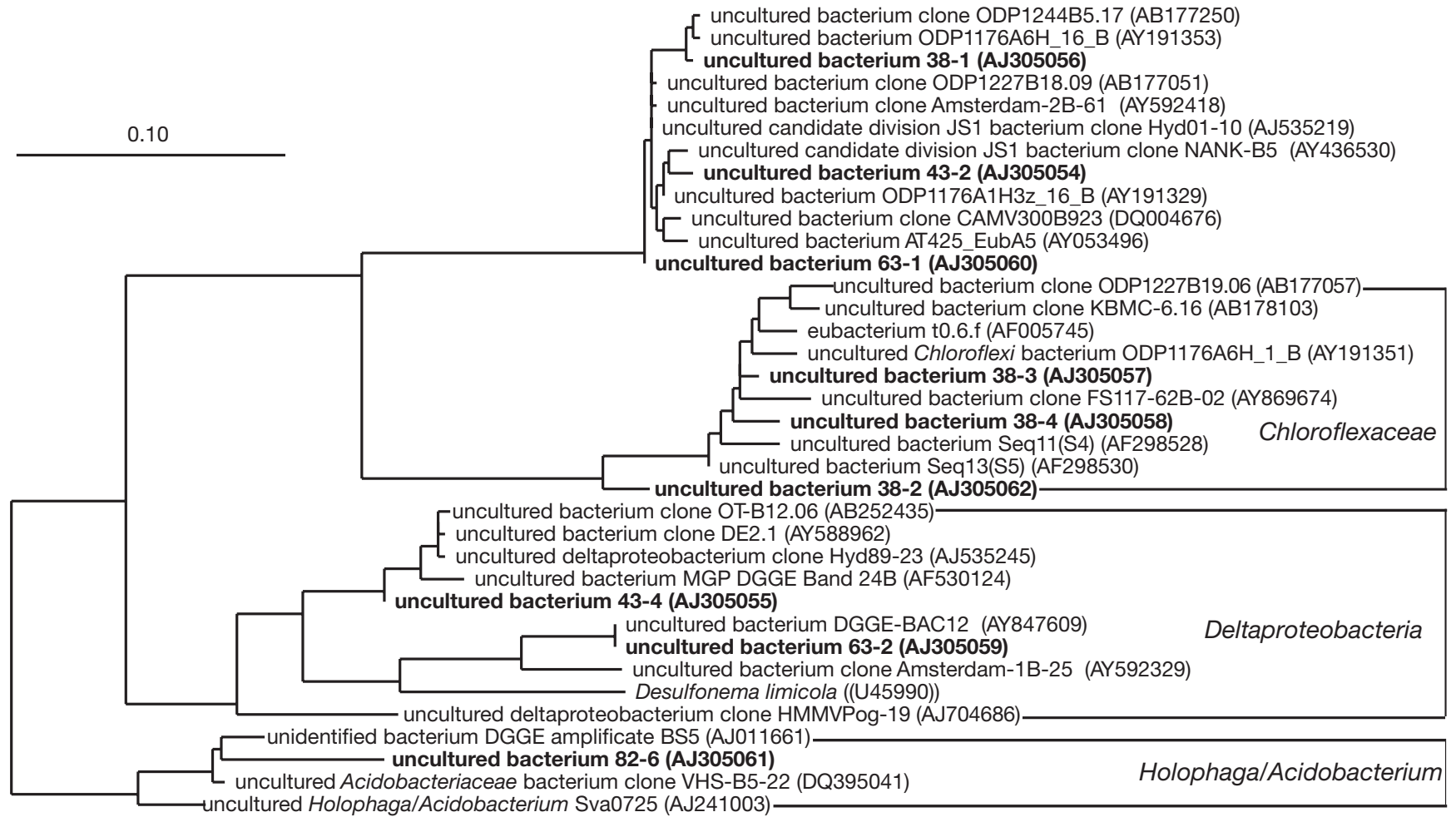

Fig. 3. Phylogenetic affiliation of bacterial 16S rRNA gene fragments obtained from excised DGGE bands. Sequences determined in this study are labeled as uncultured bacterium followed by the number of the DGGE band as indicated in Fig. 2 (e.g. uncultured bacterium 38-1), and printed in bold. The sequence of Thermus thermophilus (L09659) was used as an outgroup, but 'pruned' from the tree. Scale bar $=10 \%$ estimated sequence divergence 
Table 1. Distribution of bacterial phylotypes in the different sediment layers of the Benguela Upwelling System. SMTZ: sulfate-methane transition zone

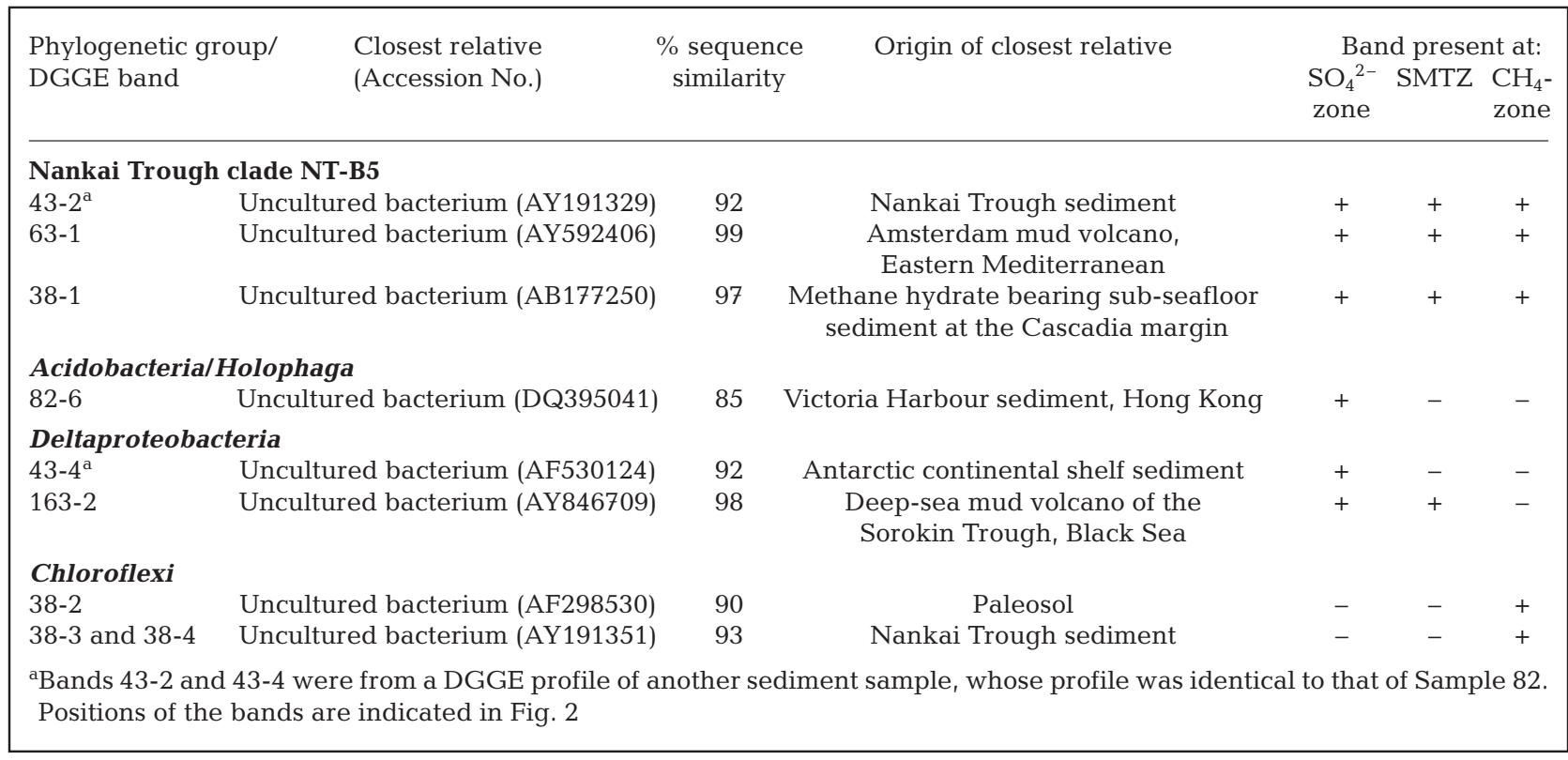

Napoli mud volcano (GenBank accession no. AY592788) and methane seep marine sediments (Inagaki et al. 2004). The similarity of the 2 samples from the methane zone below the SMTZ might indicate the existence of stable conditions (i.e. low diversity of electron acceptors and probably highly refractory carbon sources except for $\mathrm{CH}_{4}$ ).

Relatives of SRB were detected by sequencing and by hybridization analysis of DGGE patterns with radiolabeled oligonucleotide probes specific for members of different SRB groups (result not shown) in Samples 82 and 63 . Sulfate reduction rates in the surface sediment layers represented by Sample 82 were relatively high for such a water depth (up to $16 \mathrm{nmol} \mathrm{S} \mathrm{cm}{ }^{-3} \mathrm{~d}^{-1}$ ), but consistent for the high rates of organic carbon deposition characteristic of the Benguela Upwelling (Ferdelman et al. 1999). In this sample, a dominant DGGE band was identified as a population related to Desulfobacterium by hybridization with oligonucleotide probe 804 (specific for members of the genera Desulfobacter, Desulfobacterium, and Desulfosarcina variabilis, Desulfococcus multivorans, and Desulfobotulus sapovorans, see Devereux et al. 1992). The predominant DGGE band 43-4 (which was obtained from another core), however, had 2 mismatches to the probe sequence. Sequences closely related to this candidate SRB population were detected in Antarctic shelf sediments (Bowman et al. 2003), deep marine sediments of the Pacific (GenBank accession no. AY588962), sediments from a liquid $\mathrm{CO}_{2}$ lake at the Yonaguni Knoll IV hydrothermal vent field (Inagaki et al. 2006a) and in sediments above gas hydrates (Knittel et al. 2003). The corresponding DGGE band in Sample 82, which did not yield unambiguous sequence data, may therefore have been a mixture of 2 or more phylotypes, one of which was probably a complete oxidizing SRB population. Interestingly, SRB populations were not observed below the SMTZ, although there have been reports of SRB populations in the sulfidic, but sulfate-depleted, sediments of the Black Sea (Leloup et al. 2007).

Compared to the more complex DGGE fingerprints found for all other samples, the DGGE patterns for the SMTZ showed a strikingly low number of bands, further highlighting this sediment horizon as a unique zone in this sediment core. The low richness most likely reflected the presence of a specialized microbial community at the SMTZ, potentially involved in AOM, a dominant process in this zone of the sediment. One of the DGGE-defined populations at the SMTZ (DGGE band 63-2) was closely related to a population retrieved from deep sea mud volcanoes in the Black Sea, where biomarker evidence indicated the occurrence of anaerobic methane oxidation (Stadnitskaia et al. 2005).

\section{Diversity of Archaea at the SMTZ}

Biogeochemical observations in the investigated sediment core clearly indicated that AOM coupled to reduction of sulfate occurs in the SMTZ at Stn GeoB3703 (Niewöhner et al. 1998, Fossing et al. 2000). 
In marine sediments with shallow SMTZs and AOM activity, ANME Archaea and SRB have been detected by PCR-based methods (Thomsen et al. 2001, Parkes et al. 2007) and by FISH (Treude et al. 2005b). However, recent studies suggest that this may not be the case at SMTZ in deep sediments. Sørensen \& Teske (2006) found archaeal groups distinct from ANME groups to be dominant at the deep SMTZ of sediments of the Peru continental margin and showed members of a crenarchaeal clade and of MBG-B to have a higher activity at the SMTZ than at other depths. This result was consistent with the results of Biddle et al. (2006), whose additional isotopic analyses suggest that $\mathrm{CH}_{4}$ might be an energy source rather than a carbon source for these Crenarchaea. Inagaki et al. (2006b) analyzed deep methane hydrate-bearing sediments from the Pacific. While they were successful in detecting SRB of the Desulfosarcina/Desulfococcus group at the SMTZ of 3 different sites, ANME-related Archaea were only detected at low abundance at one of these SMTZ. Although it was not ruled out that ANME populations might have remained undetected due to patchy distribution or low numbers, it was suggested that ANME may have been absent from these sediments and that other unidentified phylotypes might be responsible for anaerobic oxidation of methane. The SMTZ may be a narrow zone in the sediment and thus might not be fully represented by our sample. However, the studies of Thomsen et al. (2001) and Parkes et al. (2007) have demonstrated that sediment layers surrounding the SMTZ in sediment cores may contain ANME Archaea that can be detected by PCR.

We therefore analyzed the archaeal component of the microbial community at the SMTZ of the Beguela Upwelling System by cloning and sequencing of $16 \mathrm{~S}$ rRNA encoding gene fragments in order to identify candidate populations that might be partners of the detected SRB. Fig. 4 shows the affiliation of 16S rRNA sequences obtained from randomly chosen clones. The sequences belonged to 4 different phylogenetic lineages, including 1 crenarchaeal and 3 euryarchaeal lineages related to populations detected in a variety of marine sediments including methane hydrate-bearing sediments and mud volcanoes (e.g. Thomsen et al. 2001, Knittel et al. 2005, Inagaki et al. 2006a, Sørensen $\&$ Teske 2006). Based on our clone library data, the dominant Archaea that were detected at the SMTZ belonged to the euryarchaeal Marine Benthic Group D (MBG-D) and a crenarchaeal lineage affiliated with the Marine Benthic Group C (MBG-C). Other sequences were related to 2 euryarchaeal groups that included sequences retrieved from (1) South African gold mines and various other marine and terrestrial samples, and (2) Antarctic marine and estuarine sediments. Members of the latter group had also been detected at the SMTZ of the methane hydrate-free, but organic-rich, Site 1227 at the Peru continental margin (Inagaki et al. 2006b), which could be considered as similar to the sediments of the Benguela Upwelling System.

None of the euryarchaeal sequences in this study was closely related to cultured methanogens or currently recognized ANME clades, similar to the observations from other sediments with deep SMTZ (Parkes et al. 2005, Biddle et al. 2006, Inagaki et al. 2006b, Sørensen \& Teske 2006). In the study by Sørensen \& Teske (2006), reverse transcription-PCR of 16S rRNA extracted from several horizons of a deep marine sediment showed that members of the MBG-B and MCG were more active at the SMTZ of Peru continental margin sediments than at other depths of the sediment, suggesting that these populations benefited directly or indirectly from anaerobic methane oxidation. Assuming that the archaeal component of a possible SRB-Archaea consortium present was not missed by our analyses, Archaea other than ANME groups may be involved in AOM and use different strategies as suggested by Biddle et al. (2006).

\section{SUMMARY}

Cultivation-independent analysis of samples from the sulfate-reducing, SMTZ, and methanogenic layers of the sediment at Stn GeoB3703 of the Benguela Upwelling System in Namibia showed the presence of SRB in the SMTZ and in the upper layers of the sediment, in line with high sulfate reduction rates that were measured in the upper horizons of the sediment. SRB were not detected below the SMTZ, as might be expected due to depletion of sulfate at this depth. These sulfate-depleted depths were characterized by Chloroflexi bacterial phylotypes. Their presence seems to be a common feature of many deep subseafloor sediments (Jørgensen et al. 2006).

None of the recognized groups of anaerobic methane oxidizing Archaea was detected at the SMTZ. This finding was similar to observations from other marine sediments where the depth of the SMTZ is driven by the burial and diagenesis of photosynthetically derived organic matter, rather than methane seepage or flow. It further supports the suggestion that the ability to oxidize methane anaerobically may be more widespread and not necessarily limited to relatives of Methanosarcinales and the ANME groups (Biddle et al. 2006). Ecological and/or physiological differences may be crucial for understanding how anaerobic methane oxidizers could be present in these different sediment types; on the one hand, methane seeps and gas hydrate-containing sediments with high methane 
Fig. 4. Phylogenetic affiliation of cloned archaeal 16S rRNA gene fragments obtained from the sulfate methane transition zone (i.e. Sample 63 in Fig. 1). Sequences determined in this study are labeled as uncultured archaeon 63 (e.g. uncultured archaeon 63-A4), and printed in bold. Black wedges represent taxa grouped for purposes of presentation; group name is shown. ANME: anaerobic methane-oxidizing Archaea. Scale bar $=10 \%$ estimated sequence divergence

uncultured archaeon clone OHKA1.30 (AB094526) uncultured archaeon 63-A18 (AJ305078)

uncultured archaeon clone CAVMV300A963 (DQ004667)

uncultured archaeon 63-A22 (AJ305082)

uncultured archaeon 63-A9 (AJ305070)

uncultured archaeon clone ODP1230A33.03 (AB177117)

uncultured euryarchaeote (AY436525)

uncultured archaeon 63-A4 (AJ305065

uncultured euryarchaeote clone NANK-A120 (AY436522)

uncultured archaeon 63-A11 (AJ305072)

uncultured archaeon 63-A21 (AJ305081)

uncultured archaeon 63-A20 (AJ305080)

uncultured archaeon clone BS-S-316 (AJ578149)

uncultured archaeon 63-A3 (AJ305064)

uncultured euryarchaeote clone NANK-A153 (AY436524)

uncultured archaeon 63-A19 (AJ305079)

uncultured archaeon clone ODP1244A5.5 (AB177232)

uncultured archaeon 63-A10 (AJ305071)

uncultured archaeon 63-A17 (AJ305077)

uncultured archaeon clone ODP1230A33.27 (AB177121)

uncultured archaeon TA1e6 (AF134389)

uncultured archaeon 63-A16 (AJ305076)

uncultured archaeon clone OUTa29 (DQ228623)

- uncultured archaeon clone MS140BH1062003_11 (DQ354741)

- uncultured archaeon clone OT-A08.12 (AB252422)

- uncultured archaeon 63-A1 (AJ305063)

- uncultured archaeon clone EV811-0305-a27 (DQ088713)

- uncultured archaeon clone 5H3_A21 (DQ301972)

$\leftarrow$ uncultured archaeon 63-A23 (AJ305083)

ANME-3

Methanolobus oregonensis (U20152)

- Methanosarcina barkeri (M59144)

Methanosarcina mazei (X69874)

ANME-2a

- uncultured archaeon clone OT-A17.11 (AB252424)

Methanosaeta concilii (M59146)

ANME-2C
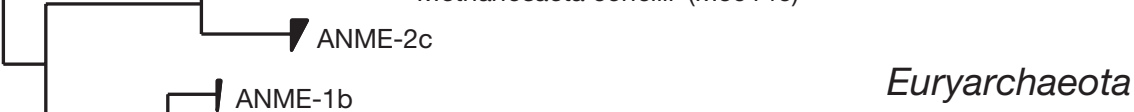

ANME-1a

ncultured euryarchaeote clone ESYB43 (AB119599) uncultured archaeon 63-A24 (AJ305084)

Thermoplasma acidophilum(M38637)

- Methanococcus jannaschii (U67517)

-Methanococcus vannielii (M36507)

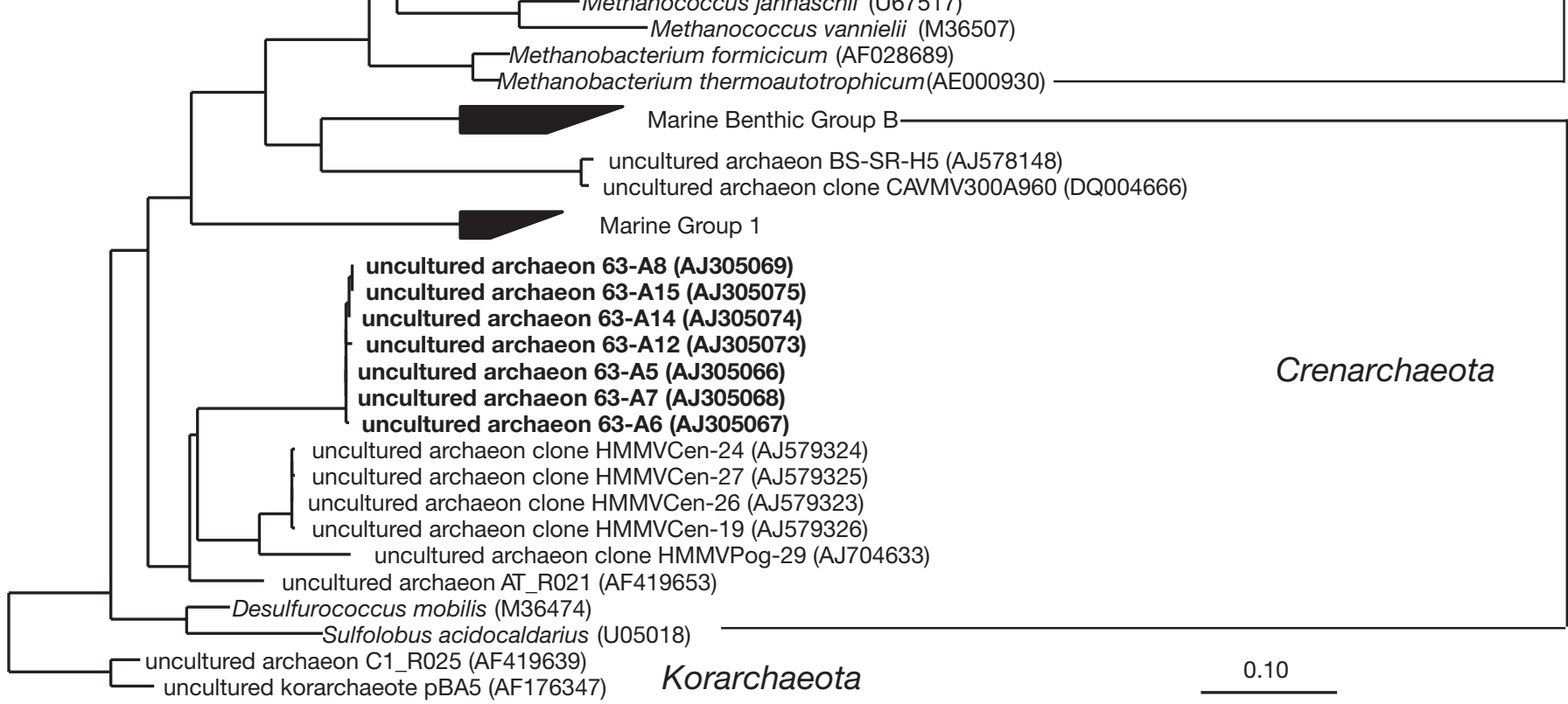

uncultured archaeon C1_R025 (AF419639)

uncultured korarchaeote pBA5 (AF176347)

Korarchaeota

0.10 
fluxes and turnover rates, and on the other hand, pelagic sediments with lower sulfate-reduction rates and low fluxes of methane. Moreover, AOM is simply not the major organic carbon oxidation process in diffusive sedimentary environments such as in the Benguela Upwelling System; therefore, the microbial communities associated with the mineralization of macro-molecular communities are more likely to dominate the patterns of diversity

Acknowledgements. The authors thank B. Rattunde, D. Minz and K. Sahm for technical advice. Captain Bruns, the crew of the RV 'Meteor', and Chief Scientist H. D. Schulz are graciously acknowledged for help in obtaining the samples. The constructive reviews and comments of 2 anonymous reviewers and the Contributing Editor are greatly appreciated. This study was supported by the German Science Foundation (DFG) and the Max Planck Society, Munich.

\section{LITERATURE CITED}

Biddle JF, Lipp JS, Lever MA, Lloyd KG and others (2006) Heterotrophic Archaea dominate sedimentary subsurface ecosystems off Peru. Proc Natl Acad Sci USA 103: 3846-3851

Boetius A, Ravenschlag K, Schubert CJ, Rickert D and others (2000) A marine microbial consortium apparently mediating anaerobic oxidation of methane. Nature 407:623-626

Bowman JP, McCammon SA, Gibson JAE, Robertson L, Nichols PD (2003) Prokaryotic metabolic activity and community structure in Antarctic continental shelf sediments. Appl Environ Microbiol 69:2448-2462

Casamayor EO, Schäfer H, Bañeras L, Pedrós-Alió C, Muyzer G (2000) Identification of and spatio-temporal differences between microbial assemblages from two neighboring sulfurous lakes: comparison by microscopy and denaturing gradient gel electrophoresis. Appl Environ Microbiol 66:499-508

Chandler DP, Brockman FJ, Bailey TJ, Fredrickson JK (1998) Phylogenetic diversity of Archaea and Bacteria in a deep subsurface paleosol. Microb Ecol 36:37-50

Devereux R, Kane MD, Winfrey J, Stahl DA (1992) Genus and group-specific hybridization probes for determinative and environmental studies of sulfate-reducing bacteria. Syst Appl Microbiol 15:601-609

Ferdelman TG, Fossing H, Neumann K, Schulz HD (1999) Sulfate reduction in surface sediments of the south-east Atlantic continental margin between $15^{\circ} 38^{\prime} \mathrm{S}$ and $27^{\circ} 57^{\prime} \mathrm{S}$ (Angola and Namibia). Limnol Oceanogr 44: $650-661$

Fossing H, Ferdelman TG, Berg P (2000) Sulfate reduction and methane oxidation in continental margin sediments influenced by irrigation (South-East Atlantic off Namibia). Geochim Cosmochim Acta 64:897-910

Hinrichs KU, Hayes JM, Sylva SP, Brewer PG, DeLong EF (1999) Methane-consuming archaebacteria in marine sediments. Nature 398:802-805

Hoehler TM, Alperin MJ, Albert DB, Martens CS (1994) Field and laboratory studies of methane oxidation in an anoxic marine sediment: evidence for a methanogen-sulfate reducer consortium. Global Biogeochem Cycles 8: 451-463

Inagaki F, Suzuki M, Takai K, Oida H and others (2003)
Microbial communities associated with geological horizons in coastal subseafloor sediments from the sea of Okhotsk. Appl Environ Microbiol 69:7224-7235

Inagaki F, Tsunogai U, Suzuki M, Kosaka A and others (2004) Characterization of C-1-metabolizing prokaryotic communities in methane seep habitats at the Kuroshima Knoll, southern Ryukyu arc, by analyzing pmoA, mmoX, mxaF, mcrA, and 16S rRNA genes. Appl Environ Microbiol 70:7445-7455

Inagaki F, Kuypers MMM, Tsunogai U, Ishibashi JI and others (2006a) Microbial community in a sediment-hosted $\mathrm{CO}_{2}$ lake of the southern Okinawa Trough hydrothermal system. Proc Natl Acad Sci USA 103:14164-14169

Inagaki F, Nunoura $\mathrm{T}$, Nakagawa $\mathrm{S}$, Teske A and others (2006b) Biogeographical distribution and diversity of microbes in methane hydrate-bearing deep marine sediments on the Pacific Ocean Margin. Proc Natl Acad Sci USA 103:2815-2820

Jørgensen BB, D'Hondt SL, Miller DJ (2006) Leg 201 synthesis: controls on microbial communities in deeply buried sediments. In: Jørgensen BB, D'Hondt SL, Miller DJ (eds) Proc ODP Sci Results 201. Ocean Drilling Program, College Station, TX, p 1-45

Knittel K, Boetius A, Lemke A, Eilers H, Lochte $\mathrm{K}$, Pfannkuche O, Linke P (2003) Activity, distribution, and diversity of sulfate reducers and other bacteria in sediments above gas hydrate (Cascadia Margin, Oregon). Geomicrobiol J 20:269-294

Knittel K, Lösekann T, Boetius A, Kort R, Amann R (2005) Diversity and distribution of methanotrophic archaea at cold seeps. Appl Environ Microbiol 71:467-479

Kormas KA, Smith DC, Edgcomb V, Teske A (2003) Molecular analysis of deep subsurface microbial communities in Nankai Trough sediments (ODP Leg 190, Site 1176). FEMS Microbiol Ecol 45:115-125

Leloup J, Loy A, Knab Nj, Borowski C, Wagner M, Jørgensen BB (2008) Diversity and abundance of sulfate-reducing microorganisms in the sulfate and methane zones of a marine sediment, Black Sea. Environ Microbiol 9:131-142

Ludwig W, Strunk O, Westram R, Richter L and others (2004) ARB: a software environment for sequence data. Nucleic Acids Res 32:1363-1371

Moran JJ, Beal EJ, Vrentas JM, Orphan VJ, Freeman KH, House CH (2008) Methyl sulfides as intermediates in the anaerobic oxidation of methane. Environ Microbiol (in press), doi: 10.1111/j.1462-2920.2007.01441.x

Muyzer G, Brinkhoff T, Nübel U, Santegoeds C, Schäfer H, Wawer C (1998) Denaturing gradient gel electrophoresis (DGGE) in microbial ecology. In: Akkermans ADL, van Elsas JD, de Bruijn FJ (eds) Molecular microbial ecology manual, Vol 3.4.4. Kluwer Academic Publishers, Dordrecht, p 1-27

Nauhaus K, Boetius A, Krüger M, Widdel F (2002) In vitro demonstration of anaerobic oxidation of methane coupled to sulphate reduction in sediment from a marine gas hydrate area. Environ Microbiol 4:296-305

Niewöhner C, Hensen C, Kasten S, Zable M, Schulz HD (1998) Deep sulfate reduction completely mediated by anaerobic methane oxidation in sediments of the upwelling area off Namibia. Geochim Cosmochim Acta 62:455-464

Orphan VJ, House CH, Hinrichs KU, McKeegan KD, DeLong EF (2002) Multiple archaeal groups mediate methane oxidation in anoxic cold seep sediments. Proc Natl Acad Sci USA 99:7663-7668

Pancost RD, Sinninghe-Damsté JS, de Lint S, van der Maarel MJEC, Gottschal JC (2000) Biomarker evidence for wide- 
spread anaerobic methane oxidation in Mediterranean sediments by a consortium of methanogenic archaea and bacteria. Appl Environ Microbiol 66:1126-1132

Parkes RJ, Webster G, Cragg BA, Weightman AJ and others (2005) Deep sub-seafloor prokaryotes stimulated at interfaces over geological time. Nature 436:390-394

Parkes RJ, Cragg BA, Banning N, Brock F and others (2007) Biogeochemistry and biodiversity of methane cycling in subsurface marine sediments (Skagerrak, Denmark). Environ Microbiol 9:1146-1161

Santegoeds CM, Ferdelman TG, Muyzer G, De Beer D (1998) Structural and functional dynamics of sulfate-reducing populations in bacterial biofilms. Appl Environ Microbiol 64:3731-3739

Schäfer H, Muyzer G (2001) Denaturing gradient gel electrophoresis in marine microbial ecology. In: Paul JH (ed) Methods in microbiology, Vol 30. Academic Press, London, p 425-468

Schäfer H, Servais P, Muyzer G (2000) Successional changes in the genetic diversity of a marine bacterial assemblage during confinement. Arch Microbiol 173:138-145

Sørensen KB, Teske A (2006) Stratified communities of active archaea in deep marine subsurface sediments. Appl Environ Microbiol 72:4596-4603

Stadnitskaia A, Muyzer G, Abbas B, Coolen MJL and others (2005) Biomarker and 16S rDNA evidence for anaerobic

Editorial responsibility: Samantha Joye,

Athens, Georgia, USA oxidation of methane and related carbonate precipitation in deep-sea mud volcanoes of the Sorokin Trough, Black Sea. Mar Geol 217:67-96

Teske A, Hinrichs KU, Edgomb V, De Vera Gomez A and others (2002) Microbial diversity of hydrothermal sediments in the Guaymas Basin: evidence for anaerobic methanotrophic communities. Appl Environ Microbiol 68: 1994-2007

Thomsen TR, Finster K, Ramsing NB (2001) Biogeochemical and molecular signatures of anaerobic methane oxidation in a marine sediment. Appl Environ Microbiol 67: $1646-1656$

Treude T, Knittel K, Blumenberg M, Seifert R, Boetius A (2005a) Subsurface microbial methanotrophic mats in the Black Sea. Appl Environ Microbiol 71:6375-6378

Treude T, Krüger M, Boetius A, Jørgensen BB (2005b) Environmental control on anaerobic oxidation of methane in the gassy sediments of Eckernförde Bay (German Baltic). Limnol Oceanogr 50:1771-1786

Webster G, Parkes RJ, Cragg BA, Newberry CJ, Weightman AJ, Fry JC (2006) Prokaryotic community composition and biogeochemical processes in deep subseafloor sediments from the Peru Margin. FEMS Microbiol Ecol 58:65-85

Zhou J, Bruns MA, Tiedje JM (1996) DNA recovery from soils of diverse composition. Appl Environ Microbiol 62: $316-322$

Submitted: June 27, 2007; Accepted: November 14, 2007 Proofs received from author(s): December 3, 2007 